\title{
INFLUENCE OF SUPPLEMENTALSHEEP RATION WITH ZINC SOURCE (INORGANIC VS. ORGANIC) ON THEIR DIGESTIBILITY AND RUMINAL FERMENTATION.
}

\author{
Safaa E.S. Atia ${ }^{1}$, A.E. El-Hais ${ }^{1}$, Sh.A. Gabr ${ }^{1}$, M.H.Yacout ${ }^{2}$; A.A. Hassan ${ }^{2}$; M.S. Khalel ${ }^{2}$ \\ ${ }^{1}$ Department of Animal Production, Faculty of agriculture, Tanta University. \\ ${ }^{2}$ Animal Production Research Institute, Agricultural Research Center, Ministry of Agriculture, Giza, \\ Egypt
}

(Received 12 11/2018, accepted 2512/2018)

\section{SUMMARY}

$\mathrm{T}$

This study was conducted to investigate the influence of zinc sulfate and zinc methionine supplementation on the nutrients digestibility, nutritive values of feeds and ruminal fermentation of sheep. Fifteen sheep averaged $(52.2 \pm 1.40 \mathrm{~kg})$ were divided into five similar groups (three animals each), they were fed basal diet containing $33.34 \mathrm{mg} \mathrm{Zn/kg} \mathrm{dry} \mathrm{matter} \mathrm{(DM)} \mathrm{with} \mathrm{no} \mathrm{supplemental} \mathrm{Zn} \mathrm{(control).} \mathrm{Control} \mathrm{group} \mathrm{was}$ consulted of concentrate feed mixture (CFM), corn silage and rice straw without zinc supplementation. The other four experimental groups supplemental with 30 or $60 \mathrm{mg}$ of $\mathrm{Zn} / \mathrm{kg}$ of DM from $\mathrm{Zn}$ sulfate (ZnS) or zinc methionine (ZnMet) to control diet. Results indicated that zinc addition either as zinc sulfate or zinc methionine increased $(\mathrm{P}<0.05)$ the digestibility of all nutrients which were reflected on the nutritive values (as TDN and DCP) of diets. Addition of zinc sulfate or zinc methionine reduced ammonia-N and increased both TVFA's rumen volume, rumen digesta and microbial protein synthesis of sheep.

Key words: Zinc sulfate, zinc methionine, digestibility, ruminal fermentation, sheep.

\section{INTRODUCTION}

Zinc is an important trace element for animals, functioning largely or entirely in enzyme systems and being involved in protein synthesis, carbohydrate metabolism, and many other biochemical reactions (Rink and Kirchner, 2000). Zinc is associated with more than 300 enzymes either as component or as activator.Zinc is an essential trace mineral that serves some roles in an animal's body such as the controlling of growth by affecting on feed intake, secretion of mitogenic hormones, gene expression of proteins(Huerta et al., 2002).The most widely used products for zinc supplementation are inorganic (zinc sulfate and zincoxide), and recently, organically bound zinc supplements are being used in animal diets (Saeidet al., 2010).

Use of organically complexed trace minerals can help prevent these losses, due to increased stability in the upper gastrointestinal tract of the animal. Indeed, a variety of trials have demonstrated greater bioavailability of organically complexed trace minerals, which in turn would allow for lower inclusion rates and reduced excretion (Baoand Choct, 2009).However, in recent years, there has been considerable interest in feeding ruminants amino-trace minerals to increase the bioavailability of the mineral above that of the soluble inorganic sources (Luo et al., 1996). The metal complex or chelate is stable in the digestive tract and is thus protected from forming complexes with other dietary components which could inhibit the absorption (Cao et al., 2000). However, $\mathrm{Zn}$ could be used to reduce ruminal degradability of feed protein and to promote greater quantities of ruminal escape protein (Britton and klopfenstein, 1986). 


\begin{abstract}
Atia et al
The objective of this study was to compare the effect of Zinc sulfate and Zinc methionine supplementation of sheep on nutrient digestibilities, nutritive values and some ruminal fermentation.

\section{MATERIALS AND METHODS}

This study was conducted in El-Noubaria, Animal Production Research Station belonging to the Animal Production Research Institute, Agricultural Research Centre, Egypt. Fifteen sheep were divided into five similar groups (three animals each). Sheep Barki Rams were fed on one of the following ration: 1Concentrate feed mixture (CFM), corn silage and rice straw without zinc supplementation (Control). 2Same as one supplemented with $30 \mathrm{mg}$ zinc sulfate $/ \mathrm{kgDMI}$. 3- Same as one supplemented with $60 \mathrm{mg}$ zinc sulfate / $/ \mathrm{kgDMI}$. 4-Same as one supplemented with $30 \mathrm{mg}$ zinc methionine $/ \mathrm{kgDMI}$. 5- Same as one supplemented with 60mg zinc methionine /kgDMI according to the feed allowances of NRC (1994). Feed additives (Zinc methionine with content of $80.5 \%$ methionine hydroxy analogue and $15.10 \%$ Zinc sulfate)and were mixed manually with some ground amounts of CFM(Multivita Company, $6^{\text {th }}$ October city,Egypt).Ingredient and chemical composition of CFM, corn silage and rice straw are presented in Table (1).
\end{abstract}

Table (1): Proximate analysis of concentrate feed mixture (CFM, corn silage and rice straw fed to sheep on DM basis (\%).

\begin{tabular}{lccc}
\hline Item & CFM & Corn silage & Rice straw \\
\hline DM & 89.53 & 29.53 & 89.54 \\
OM & 93.83 & 93.84 & 90.63 \\
CP & 16.22 & 7.98 & 3.22 \\
CF & 8.46 & 23.27 & 31.45 \\
EE & 3.16 & 2.44 & 1.08 \\
NFE & 65.99 & 60.15 & 54.88 \\
Ash & 6.17 & 6.16 & 9.37 \\
NDF & 34.84 & 48.63 & 74.36 \\
ADF & 22.06 & 27.55 & 59.14 \\
ADL & 2.77 & 4.38 & 11.47 \\
Non-fiber carbohydrate & 39.61 & 34.79 & 11.97 \\
Net energy of lactation (M & 1.37 & 0.86 & 0.47 \\
cal/kg DM) & & & \\
Calcium (g/kg of DM) & 0.66 & 0.27 & 0.17 \\
Phosphorus (g/kg of DM) & 0.25 & 0.19 & 0.11 \\
Zn (mg/kg) & 41.7 & 21.2 & 16.7 \\
\hline *CFM contained Corn grain,(ground)40\%, wheat bran 20.5 \%, Soybean, meal 44\%CP 16.5 \%, Undecorticated \\
Cottonseed meal5 \%, Sunflower cake5.5 \%, Sugar Beat pulp 6\%, Molasses 3\%, Limestone 2\%, Sodium chloride 1.1\% \\
and mineral premix 0,4\% & & &
\end{tabular}

\title{
Digestibility and nitrogen balance trials:
}

Digestibility and nitrogen balance trials were carried out using fifteen Barki rams $(52.2 \pm 1.40 \mathrm{~kg}$, in average) (three rams for each group). Each trial lasted for four weeks; the first three weeks were as a preliminary period, followed by one week for feces and urine collection. Sheep were fed twice daily at 8 am and $3 \mathrm{pm}$, water was offered freely. Each animal was offered the experimental rations according to NRC, (1994). Chemical composition of feeds, feces and urine were determined according to AOAC (2005) methods. Sub samples (20\%) of feces and urine were taken once daily then stored at $-18{ }^{\circ} \mathrm{C}$ until analyses. Fecal samples were dried at $60^{\circ} \mathrm{C}$ for $72 \mathrm{hrs}$. Feed and fecal samples were ground through $1 \mathrm{~mm}$ screen on a Wiley mill grinder and a sample of $50 \mathrm{gm} /($ ration/sheep) was taken for analysis. The samples of feed and 
feces were analyzed for crude protein (CP), crude fiber (CF), ether extract (EE) and ash, while the urine samples were analyzed for nitrogen $(\mathrm{N})$ content according to AOAC (2005). Cell wall constituents (NDF, ADF and ADL) were determined according to VanSoest (1991). Hemicellulose and cellulose were calculated by differences.

\section{Rumen fermentation trials:}

Samples of rumen liquor were taken at $0,1,3$ and $6 \mathrm{~h}$ post feeding from three ruminally-canulated Barki ewes with approximately $42.5 \pm 0.5 \mathrm{~kg}$ BWfor each treatment, to be immediately analyzed for $\mathrm{pH}$ using Orion 680 digital $\mathrm{pH}$ meter. The rumen fluid samples were preserved for ammonia nitrogen (NH3-N) determination according to Preston (1995). Concentration of total volatile fatty acid (VFA's) was estimated by using steam methods (Warner, 1964). Rumen volume was determined by colorimetric method of crEDTA before, 3 and $6 \mathrm{hrs}$ after feeding (El-Shazly et al. 1976). The microbial protein synthesized (gMP/day) in the rumen of sheep fed the experimental diets was calculated using the model equation by Borhami et al. (1992) as follow: g MP / day = mole VFA produced / day X 2 X 13.48 X 10.5 X 6.25 / 100.

where one mole VFA yield about 2 mole ATP (Walker, 1965), one mole ATP produce 13.48 YATP (g DM microbial cell); Borhami et al. (1979), $\mathrm{N} \%$ of dry microbial cell $=10.5$ (Hungate, 1965).

\section{Statistical analysis:}

Data were statistically analyzed as $(2 \times 2)$ factorial designs using tow - way ANOVA design procedure of SAS (2006); the model describing each trait was assumed to be:

$Y_{i}=\beta_{0}+\beta_{1 z l i}+\beta_{2 z 2 i}+\beta_{3 z 1 \text { izzi }}+e_{i}$

Where:

$\mathrm{Y}_{\mathrm{i}}=$ outcome score for the $\mathrm{i}_{\mathrm{th}}$ unit

$\beta_{0}=$ coefficient for the intercept

$\beta_{1}=$ mean difference on levels

$\beta_{2}=$ mean difference on zinc sources

$\beta_{3}=$ interaction of levels and zinc sources

$\mathrm{z}_{1 \mathrm{i}}=$ dummy variable for levels

$\mathrm{z}_{2 \mathrm{i}}=$ dummy variable for zinc sources

$\mathrm{e}_{\mathrm{i}}=$ residual for the $\mathrm{i}_{\mathrm{th}}$ unit

Separation among means was carried out by using Duncan's Multiple Range Test, (Duncan, 1955).

\section{RESULTS AND DISCUSSION}

\section{Feed intake and Nutrient digestibilities:}

The results presented in Table (2) showed that intake DM was insignificant $(\mathrm{P}>0.05)$ between treatments. No significant differences of DM intake among treatments (Table 2). Miller et al. (1989) reported that supplementation of $\mathrm{Zn}$ (ZnSO4) up to $2000 \mathrm{ppm}$ of the diet did not influence DMI in dairy cows. These were also observed by Gaafar et al. (2011). However, daily Zn intake (33.34 up to 94.48) seems to be less than that was recommended by NRC (2001) $(130-180 \mathrm{mg} /$ day). In the same manner, Salama et al. (2003) noticed that supplementing dairy goats with $1 \mathrm{~g} / \mathrm{d}$ ZnMet resulted in an increase of DM, CP and OM digestibility. They also reported that supplementing with $20 \mathrm{mg}$ organic $\mathrm{Zn}$ improved NDF digestibility as a positive role in its effect in fiber digestion. In the meantime, Garg et al. (2008) found that supplementation with $20 \mathrm{mg}$ organic zinc improved digestibility of both cellulose and ADF. However, the improvement in digestibility could be due to the direct role of ZnMet in stimulating anaerobic fermentation of OM which in turn could improve the efficiency of nutrients utilization. Data presented in Table (2) 


\begin{abstract}
Atia et al
indicated that supplemental $60 \mathrm{mg} / \mathrm{kg}$ DM zinc methionine significantly $(\mathrm{P}<0.05)$ increased the all nutrient digestibilities and cell wall constituents (NDF, ADF and ADL) compared to other groups. While supplemented of two different levels of zinc methionine significantly $(\mathrm{P}<0.05)$ increased the all nutrient digestibilities and cell wall constituents (NDF, ADF and ADL) compared to two different levels of zinc sulfate and control groups, Also, no significant differences were found between the two $\mathrm{Zn}$ sources of EE digestibility. The higher apparent digestibility coefficient with zinc supplemented rations may be due to the improvement of their digestibility and absorption. These results are in line with those obtained by Shakweer et al. (2005) who found that the apparent digestibility of DM, OM, CP and CF were significantly improved with added different levels of zinc methionine in the ration of Friesian dairy cows. Mandal et al. (2007) indicated that a diet containing about $32.5 \mathrm{mg} \mathrm{Zn/kg} \mathrm{DM}$ was adequate to support normal growth and digestibility in bulls.Mousa and EL-Sheikh, (2004) found that the apparent digestibility of $\mathrm{DM}, \mathrm{OM}, \mathrm{CP}, \mathrm{CF} ; \mathrm{EE}$ and NFE were slightly increased by different levels of zinc sulfate supplementation to the ration of lactating buffaloes. However, Dinn et al. (1998) reported that the apparent digestibility of CF was significantly increased with addition of protected amino acids than those of unprotected. Balabanovaet al. (2011) indicated that the feeding organic forms of zinc a tendency to higher digestibility of crude protein, fat, crude fiber, nitrogen-free extracts and ash compared to inorganic forms of zinc. Also, the digestibility of the fiber was the most increased.
\end{abstract}

Table (2). Effect of different levels of zinc sulfate or zinc methionine supplementation on feed intake and digestibility coefficient in sheep.

\begin{tabular}{|c|c|c|c|c|c|c|}
\hline \multirow{3}{*}{ Item } & & \multirow[b]{3}{*}{ Control } & \multicolumn{4}{|c|}{ Zinc supplement } \\
\hline & & & \multicolumn{2}{|c|}{ Inorganic $\mathrm{Zn}$} & \multicolumn{2}{|c|}{ Organic Zn } \\
\hline & & & $\begin{array}{l}\text { Zinc Sulfate, } \\
30 \mathrm{mg} / \mathrm{kg} \text { DM }\end{array}$ & $\begin{array}{l}\text { Zinc Sulfate, } \\
60 \mathrm{mg} / \mathrm{kg} \text { DM }\end{array}$ & $\begin{array}{c}\text { Zinc } \\
\text { Methionine, } \\
\text { 30mg/kg DM }\end{array}$ & $\begin{array}{c}\text { Zinc } \\
\text { Methionine, } \\
\text { 60mg/kg DM }\end{array}$ \\
\hline \multicolumn{7}{|c|}{ Feed intake, $(\mathrm{g} / \mathrm{h} / \mathrm{d})$} \\
\hline \multirow{3}{*}{\multicolumn{2}{|c|}{$\begin{array}{l}\text { CFM } \\
\text { Corn silage }\end{array}$}} & 537.2 & 537.2 & 537.2 & 537.2 & 537.2 \\
\hline & & 339.6 & 363.2 & 367.7 & 371.2 & 380.77 \\
\hline & & \pm 26.3 & \pm 20.6 & \pm 17.9 & \pm 28.5 & \pm 42.0 \\
\hline \multirow{2}{*}{\multicolumn{2}{|c|}{ Rice straw }} & 223.8 & 237.9 & 240 & 245.3 & 240.00 \\
\hline & & \pm 10.7 & \pm 19.5 & \pm 13.1 & \pm 9.4 & \pm 13.2 \\
\hline \multirow{2}{*}{\multicolumn{2}{|c|}{$\begin{array}{l}\text { Total feed } \\
\text { intake }\end{array}$}} & 1100.7 & 1137.7 & 1144.8 & 1153.7 & 1157.8 \\
\hline & & \pm 47.04 & \pm 34.0 & \pm 41.5 & \pm 27.2 & \pm 38.6 \\
\hline \multirow{2}{*}{\multicolumn{3}{|c|}{$\begin{array}{l}\mathrm{Zn} \text { conc. } \\
\text { Intake, } \mathrm{mg} / \mathrm{kg}\end{array}$}} & 64.06 & 94.20 & 64.37 & 94.48 \\
\hline & & & & & & \\
\hline \multicolumn{7}{|c|}{ DM } \\
\hline \multicolumn{7}{|c|}{ Digestibility (\%) } \\
\hline $\mathrm{DM}$ & & $4 \pm 1.07^{\mathrm{d}}$ & $59.72 \pm 0.83^{c}$ & $60.33 \pm 0.66^{c}$ & $61.65 \pm 0.19^{\mathrm{b}}$ & $62.38 \pm 0.28^{\mathrm{a}}$ \\
\hline $\mathrm{OM}$ & & $3 \pm 0.73^{c}$ & $62.67 \pm 1.58^{\mathrm{b}}$ & $63.27 \pm 1.08^{\mathrm{b}}$ & $64.49 \pm 0.34^{\mathrm{b}}$ & $65.10 \pm 0.16^{\mathrm{a}}$ \\
\hline $\mathrm{CP}$ & & $4 \pm 0.66^{\mathrm{c}}$ & $65.68 \pm 0.47^{b}$ & $65.88 \pm 0.72^{b}$ & $67.14 \pm 0.26^{\mathrm{a}}$ & $67.69 \pm 0.43^{a}$ \\
\hline $\mathrm{CF}$ & & $4 \pm 0.93^{c}$ & $61.16 \pm 0.44^{\mathrm{b}}$ & $61.71 \pm 0.73^{\mathrm{b}}$ & $63.15 \pm 0.42^{\mathrm{a}}$ & $63.64 \pm 0.28^{\mathrm{a}}$ \\
\hline $\mathrm{EE}$ & & $6 \pm 0.53^{b}$ & $72.41 \pm 0.74^{\mathrm{a}}$ & $72.52 \pm 0.92^{\mathrm{a}}$ & $72.39 \pm 0.68^{a}$ & $72.08 \pm 0.55^{\mathrm{a}}$ \\
\hline NFE & & $3 \pm 1.07^{\mathrm{c}}$ & $62.19 \pm 0.47^{\mathrm{b}}$ & $62.93 \pm 0.89^{\mathrm{b}}$ & $64.10 \pm 0.10^{\mathrm{a}}$ & $64.79 \pm 0.68^{a}$ \\
\hline \multicolumn{7}{|c|}{ Cell wall constituents $(\%)$} \\
\hline NDF & & $8 \pm 0.52^{\mathrm{c}}$ & $60.97 \pm 0.78^{\mathrm{b}}$ & $61.60 \pm 0.62^{\mathrm{b}}$ & $61.97 \pm 0.59^{b}$ & $63.52 \pm 0.33^{\mathrm{a}}$ \\
\hline $\mathrm{ADF}$ & & $6 \pm 0.69^{c}$ & $47.13 \pm 0.28^{\mathrm{b}}$ & $47.43 \pm 0.36^{\mathrm{b}}$ & $49.45 \pm 0.48^{a}$ & $50.24 \pm 0.68^{a}$ \\
\hline Lignin & & $8 \pm 0.19^{c}$ & $36.06 \pm 0.55^{\mathrm{b}}$ & $37.11 \pm 0.83^{\mathrm{b}}$ & $38.83 \pm 0.44^{\mathrm{b}}$ & $39.95 \pm 0.27^{\mathrm{a}}$ \\
\hline
\end{tabular}




\section{Nutritive values:}

Nutritive values expressed as TDN, DCP, DE and ME were $(\mathrm{P}<0.05)$ increased by the supplementation of the two different levels of zinc methionine compared to the two levels of zinc sulfate and control groups (Table 3).The improved TDN and DCP might be due to the higher nutrients digestibility of zinc supplemented groups. These results are in accordance with Shakweer et al. (2005) and Mousa and ELSheikh (2004) who found that the TDN and DCP were significantly increased by added different levels of zinc methionine or zinc sulfate. However, the improvement in nutrients digestibility in relation to increase Zn supplementation level, was accompanied by the improvement in the nutritive value of the given diet expressed either as Kcal metabolizable energy (ME) or as digestable crude protein (DCP) (Rothet al., 1992).

Table (3). Effect of different levels of zinc sulfate or zinc methionine supplementation on nutritive values in sheep.

\begin{tabular}{|c|c|c|c|c|c|}
\hline \multirow[b]{3}{*}{ Item } & \multirow[b]{3}{*}{ Control } & \multicolumn{4}{|c|}{ Zinc supplement } \\
\hline & & \multicolumn{2}{|c|}{ Inorganic $\mathrm{Zn}$} & \multicolumn{2}{|c|}{ Organic Zn } \\
\hline & & $\begin{array}{l}\text { Zinc Sulfate, } \\
30 \mathrm{mg} / \mathrm{kg} \mathrm{DM}\end{array}$ & $\begin{array}{l}\text { Zinc Sulfate, } \\
60 \mathrm{mg} / \mathrm{kg} \mathrm{DM}\end{array}$ & $\begin{array}{c}\text { Zinc Methionine, } \\
\text { 30 } \mathrm{mg} / \mathrm{kg} \mathrm{DM}\end{array}$ & $\begin{array}{c}\text { Zinc Methionine, } \\
60 \mathrm{mg} / \mathrm{kg} \mathrm{DM}\end{array}$ \\
\hline TDN, \% & $57.76 \pm 0.21^{\mathrm{c}}$ & $60.65 \pm 0.44^{\mathrm{b}}$ & $61.17 \pm 0.61^{b}$ & $62.32 \pm 0.22^{\mathrm{a}}$ & $62.90 \pm 0.74^{\mathrm{a}}$ \\
\hline TDNI, $\mathrm{g}$ & $635.74 \pm 23.73^{c}$ & $690.02 \pm 10.33^{b}$ & $700.29 \pm 9.84^{\mathrm{b}}$ & $719.01 \pm 7.88^{\mathrm{a}}$ & $728.27 \pm 13.59^{\mathrm{a}}$ \\
\hline $\mathrm{DCP}, \%$ & $6.98 \pm 0.03^{c}$ & $7.14 \pm 0.10^{\mathrm{b}}$ & $7.15 \pm 0.08^{\mathrm{ab}}$ & $7.25 \pm 0.11^{\mathrm{a}}$ & $7.32 \pm 0.09^{\mathrm{a}}$ \\
\hline DCPI, g & $76.83 \pm 1.38^{\mathrm{c}}$ & $81.23 \pm 0.62^{\mathrm{b}}$ & $81.85 \pm 0.44^{b}$ & $83.65 \pm 0.89^{a}$ & $84.75 \pm 1.03^{\mathrm{a}}$ \\
\hline $\mathrm{DE}(\mathrm{M} \mathrm{cal} / \mathrm{kg})$ & $2.55 \pm 0.05^{\mathrm{c}}$ & $2.67 \pm 0.02^{\mathrm{b}}$ & $2.70 \pm 0.05^{\mathrm{ab}}$ & $2.75 \pm 0.03^{\mathrm{a}}$ & $2.77 \pm 0.02^{\mathrm{a}}$ \\
\hline $\mathrm{ME}\left(\mathrm{Mcal} \mathrm{kg}{ }^{-1}\right)$ & $2.09 \pm 0.04^{\mathrm{b}}$ & $2.20 \pm 0.03^{\mathrm{a}}$ & $2.21 \pm 0.06^{\mathrm{a}}$ & $2.26 \pm 0.04^{\mathrm{a}}$ & $2.28 \pm 0.06^{\mathrm{a}}$ \\
\hline
\end{tabular}

a,b,c: means in the same row followed by different superscripts are significantly $(\mathrm{P}<0.05)$ different

\section{Nitrogen utilization}

The data of nitrogen intake in table (4) showed that no significant differences were found between the supplemental $\mathrm{Zn}$ and control groups of nitrogen intake. The presented results indicated that dietary the

Table (4). Effect of different levels of zinc sulfate or zinc methionine supplementation on nitrogen utilizationin sheep.

\begin{tabular}{|c|c|c|c|c|c|}
\hline \multirow[b]{3}{*}{ Item } & \multirow[b]{3}{*}{ Control } & \multicolumn{4}{|c|}{ Zinc supplement } \\
\hline & & \multicolumn{2}{|c|}{ Inorganic $\mathrm{Zn}$} & \multicolumn{2}{|c|}{ Organic Zn } \\
\hline & & $\begin{array}{l}\text { Zinc Sulfate, } \\
30 \mathrm{mg} / \mathrm{kg} \text { DM }\end{array}$ & $\begin{array}{l}\text { Zinc Sulfate, } \\
60 \mathrm{mg} / \mathrm{kg} \text { DM }\end{array}$ & $\begin{array}{c}\text { Zinc } \\
\text { Methionine, } \\
\text { 30mg/kg DM }\end{array}$ & $\begin{array}{c}\text { Zinc } \\
\text { Methionine, } \\
60 \mathrm{mg} / \mathrm{kg} \mathrm{DM}\end{array}$ \\
\hline Nitrogen intake (NI), g/d & $19.43 \pm 0.74$ & $19.80 \pm 0.48$ & $19.87 \pm 0.52$ & $19.94 \pm 0.57$ & $20.04 \pm 0.68$ \\
\hline Nitrogen absorbed (NA), g/d & $12.29 \pm 0.33^{\mathrm{b}}$ & $13.01 \pm 0.49^{\mathrm{a}}$ & $13.09 \pm 0.13^{\mathrm{a}}$ & $13.39 \pm 0.11^{\mathrm{a}}$ & $13.56 \pm 0.17^{\mathrm{a}}$ \\
\hline Nitrogen retained (NR), g/d & $4.29 \pm 0.22^{c}$ & $4.96 \pm 0.15^{\mathrm{b}}$ & $5.16 \pm 0.10^{\mathrm{b}}$ & $5.13 \pm 0.17^{\mathrm{b}}$ & $5.57 \pm 0.21^{\mathrm{a}}$ \\
\hline $\mathrm{N}$ - retained e as $\%$ of $\mathrm{N}$-intake & $22.10 \pm 0.29^{c}$ & $25.07 \pm 0.37^{\mathrm{b}}$ & $25.95 \pm 0.55^{\mathrm{b}}$ & $25.71 \pm 0.26^{\mathrm{b}}$ & $27.81 \pm 0.17^{\mathrm{a}}$ \\
\hline $\mathrm{N}$ - retained as $\%$ of $\mathrm{N}$-absorbed & $34.94 \pm 0.55^{\mathrm{c}}$ & $38.18 \pm 1.03^{\mathrm{b}}$ & $39.38 \pm 0.75^{\mathrm{b}}$ & $38.30 \pm 0.89^{\mathrm{b}}$ & $41.08 \pm 0.39^{\mathrm{a}}$ \\
\hline Zinc conc. In faces, mg/h/d & 0.96 & 8.04 & 14.18 & 9.22 & 15.27 \\
\hline
\end{tabular}

${ }_{a, b, c:}$ means in the same row followed by different superscripts are significantly $(P<0.05)$ different

supplemental $60 \mathrm{mg} / \mathrm{kg}$ DM zinc methionine significantly $(\mathrm{P}<0.05)$ increased the nitrogen retained $(\mathrm{NR}), \mathrm{N}-$ retained as $\%$ of $\mathrm{N}$-intake and as $\%$ of $\mathrm{N}$-absorbed compared to other groups, while supplement of two different levels of zinc sulfate and zinc methionine significantly $(\mathrm{P}<0.05)$ increased the nitrogen absorbed (NA) compared to control group. However, all rations were showed positive retained N. Differences in nitrogen retained values may be due to the differences in amino acids composition of protein sources and its 


\begin{abstract}
Atia et al
digestibility. The higher percentage of dietary nitrogen retained noticed with ration supplemental $60 \mathrm{mg} / \mathrm{kg}$ DM zinc methionine compared with the control, these may be due to the more digestible protein; it had more $(\mathrm{P}<0.05)$ nitrogen utilization, this finding was agreed with that of Kleinschmit et al. (2006).Dietary nitrogen utilization $(\% \mathrm{~N}$ retained of $\mathrm{N}$-intake) was obviously higher $(\mathrm{P}<0.05)$ with ration supplemented with 60 $\mathrm{mg} / \mathrm{kg}$ DM zinc methionine, than the all other rations.
\end{abstract}

\title{
Ruminal fermentation:
}

Ruminal $\mathrm{pH}$ and ruminal metabolites $\left(\mathrm{NH}_{3}-\mathrm{N}\right.$ and TVFA' $\left.\mathrm{S}\right)$ values were significantly affected by supplementation of zinc (Table 5). The $\mathrm{pH}$ value of rumen liquor were significantly $(\mathrm{P}<0.05)$ decreased by supplemental inorganic or organic zinc compared with control group. The $\mathrm{pH}$ values are within the normal range obtained by Van Soest (1982) who stated that the optimum $\mathrm{pH}$ value for growth of cellulytic microorganisms was $6.7 \pm 0.5 \mathrm{pH}$ degree. Supplemental with $60 \mathrm{mg} / \mathrm{kg}$ DM zinc methionine had significantly $(\mathrm{P}<0.05)$ decreased the $\mathrm{NH}_{3}$-Nandrate of out flow compared to control group. However, supplementation with organic zinc had more proration than inorganic zinc in that concern. While, the concentrations of TVFA's, rumen volume, rumen digesta and microbial protein synthesis significantly increased $(\mathrm{P}<0.05)$ with30 and $60 \mathrm{mg} / \mathrm{kg}$ DM zinc methionine compared 30 and $60 \mathrm{mg} / \mathrm{kg}$ zinc sulfate and control groups. This increase in TVFA's may be due to the increase of apparent digestibility of organic matter. These results suggested that the anaerobic fermentation of protected amino acids were more efficient and faster yielding more TVFA's than that in control and inorganic supplementation. The decrease of ruminal $\mathrm{NH}_{3}-\mathrm{N}$ concentration with zinc methionine supplementation may be due to improve of the rumen microbe's activity utilizing $\mathrm{NH}_{3}-\mathrm{N}$ to produce microbial protein, in the meantime, improve degradation of feed utilization (Froetschel et al., 1990). Hideaki et al. (2005) found that feeding zinc methionine to Japanese black steers was more effective in ruminal fermentation than inorganic zinc. Spears et al. (2004) showed that total VFA concentrations were higher $(\mathrm{P}<0.05)$ in steers receiving ZnGly or ZnMet than in those fed the control and $\mathrm{ZnSO}_{4}$ treatments. Increased acetate and decrease butyrate with $\mathrm{ZnMet}$ is consistent with improved microbial efficiency of energy utilization (France and Siddons, 1993). Arelovich et al.(1998) reported that concentration of $\mathrm{NH}_{3}-\mathrm{N}$ was decreased by added $\mathrm{Zn}$. This might be due to that zinc sulfate depress urease activity directly or it might inhibit growth and reduce the population of ureolytic bacteria (Arelovich et al., 2000). Shakweer et al. (2006) reported that the increase proportion of propionate in ruminal VFA's leads to an increase in energetic efficiency of ruminal fermentation which may explain the consistent benefits obtained from addition of chelated zinc.

Table (5). Effect of different levels of zinc sulfate or zinc methionine supplementation on someruminal fermentation ofsheep.

\begin{tabular}{|c|c|c|c|c|c|}
\hline \multirow[b]{3}{*}{ Item } & \multirow[b]{3}{*}{ Control } & \multicolumn{4}{|c|}{ Zinc supplement } \\
\hline & & \multicolumn{2}{|c|}{ Inorganic Zn } & \multicolumn{2}{|c|}{ Organic Zn } \\
\hline & & $\begin{array}{l}\text { Zinc Sulfate, } \\
30 \mathrm{mg} / \mathrm{kg} \text { DM }\end{array}$ & $\begin{array}{l}\text { Zinc Sulfate, } \\
60 \mathrm{mg} / \mathrm{kg} \text { DM }\end{array}$ & $\begin{array}{c}\text { Zinc } \\
\text { Methionine, } \\
\text { 30mg/kg DM }\end{array}$ & $\begin{array}{c}\text { Zinc } \\
\text { Methionine, } \\
\text { 60mg/kg DM }\end{array}$ \\
\hline $\mathrm{pH}$ & $6.69 \pm 0.02^{\mathrm{a}}$ & $6.55 \pm 0.01^{b}$ & $6.47 \pm 0.01^{\mathrm{c}}$ & $6.48 \pm 0.01^{\mathrm{c}}$ & $6.45 \pm 0.01^{\mathrm{d}}$ \\
\hline $\begin{array}{l}\text { Ammonia nitrogen } \\
\text { concentration }(\mathrm{mg} / 100 \mathrm{ml})\end{array}$ & $15.05 \pm 0.13^{\mathrm{a}}$ & $12.70 \pm 0.17^{b}$ & $12.55 \pm 0.15^{\mathrm{b}}$ & $12.29 \pm 0.08^{c}$ & $12.16 \pm 0.13^{\mathrm{c}}$ \\
\hline $\begin{array}{l}\text { Total Volatile fatty acids } \\
\text { concentration(TVFA) } \\
(\mathrm{mmol} / 100 \mathrm{ml})\end{array}$ & $10.46 \pm 0.13^{\mathrm{c}}$ & $11.46 \pm 0.05^{\mathrm{b}}$ & $11.55 \pm 0.12^{\mathrm{b}}$ & $11.83 \pm 0.09^{\mathrm{a}}$ & $12.05 \pm 0.11^{\mathrm{a}}$ \\
\hline Rumen volume (L) & $3.08 \pm 0.15^{\mathrm{c}}$ & $3.65 \pm 0.12^{\mathrm{b}}$ & $3.72 \pm 0.06^{\mathrm{b}}$ & $3.94 \pm 0.07^{\mathrm{a}}$ & $4.05 \pm 0.11^{\mathrm{a}}$ \\
\hline Acetate & $54.64 \pm 0.36^{\mathrm{b}}$ & $57.59 \pm 0.57^{\mathrm{a}}$ & $58.13 \pm 0.38^{\mathrm{a}}$ & $58.16 \pm 0.32^{\mathrm{a}}$ & $58.44 \pm 0.29^{\mathrm{a}}$ \\
\hline Propionate & $25.77 \pm 0.36^{\mathrm{a}}$ & $24.37 \pm 0.26^{\mathrm{b}}$ & $24.25 \pm 0.23^{\mathrm{b}}$ & $23.86 \pm 0.07^{\mathrm{c}}$ & $23.10 \pm 0.43^{\mathrm{c}}$ \\
\hline Butyrate & $10.96 \pm 0.45^{\mathrm{a}}$ & $6.41 \pm 0.19^{\mathrm{b}}$ & $5.24 \pm 0.06^{\mathrm{c}}$ & $5.10 \pm 0.10^{c}$ & $4.30 \pm 0.22^{\mathrm{d}}$ \\
\hline Rate of out flow (\% hr) & $7.29 \pm 0.06^{\mathrm{a}}$ & $5.65 \pm 0.04^{\mathrm{b}}$ & $5.60 \pm 0.07^{\mathrm{b}}$ & $5.22 \pm 0.05^{\mathrm{c}}$ & $5.10 \pm 0.14^{\mathrm{c}}$ \\
\hline Rumen digesta $(\mathrm{kg})$ & $3.48 \pm 0.25^{\mathrm{c}}$ & $4.13 \pm 0.13^{\mathrm{b}}$ & $4.25 \pm 0.07^{\mathrm{ab}}$ & $4.32 \pm 0.02^{\mathrm{a}}$ & $4.43 \pm 0.11^{\mathrm{a}}$ \\
\hline $\begin{array}{l}\text { Microbial protein synthesis } \\
\text { (MP, g/d) }\end{array}$ & $40.87 \pm 1.08^{\mathrm{d}}$ & $62.57 \pm 1.04^{\mathrm{c}}$ & $70.76 \pm 2.61^{b}$ & $74.05 \pm 3.62^{\mathrm{b}}$ & $79.20 \pm 0.53^{\mathrm{a}}$ \\
\hline
\end{tabular}




\section{CONCLUSION}

From the present study it can be concluded that dietary supplement either30 or $60 \mathrm{mg} \mathrm{Zn}$ to the diet, showed beneficial supplement effects to improve nutritive value and ruminal activity of ram barki.

\section{REFERENCES}

AOAC (2005) Official methods of analysis, $18^{\text {th }}$ ed. Association of Official Analytical Chemists, Washington, DC.

Arelovich, H.M. (1998). Effects of zinc and manganese on digestion, ruminal and bloodparameters of cattle fed prairie hay. Ph. D. Thesis, Oklahoma State University, USA.

Arelovich, H.M.; F.N. Owens; G.W. Horn and J.A. Vizcarra, 2000. Effect of supplemented zinc and manganese on ruminal fermentation, forage intake and digestion by cattle fed prairie hay and urea. J.Anim. Sci. 78: 2972-2979.

Balabanova, M., Hoškova, Š., Zeman, L.(2011). The effect of inorganic and organic form of zinc on digestibility of nutrients in dairy cows in three stages of reproductive cycle.Acta Universitatis Agriculturae Et Silviculturae Mendelianae Brunensis. LIX, No. 6, pp. 17-24.

Bao, Y. M. and M. Choct. 2009. Trace mineral nutrition for broiler chickens and prospects of application of organically complexed trace minerals: a review. Anim. Prod. Sci. 49:269-282.

Borhami, B.E.A.; K. El-Shazly; A.R. Abou-Akkada; M.A., Naga; A.M. Nour and M.A. Abaza (1979) Nitrogen $\left({ }^{15} \mathrm{~N}\right)$ utilization and microbial protein synthesis in the rumen of urea fed cattle. J. Anim. Sci., 49: 1306.

Borhami, B.E.A.; W.G. Fahmy and K. El-Shazly (1992). Rumen environment microbial protein synthesis and nitrogen balance in sheep. In: A Proceeding of "Manipulation of rumen micro-organisms". Inter. Confe. from 20-23 Sept. 1992.

Britton, R.A. and T.S. Klopfenstein, 1986. Zinc treated soy bean meal: a method to increase by pass page 45in Nebraska Beef Cattle Rep. Mp.so Univ. Nebraka. Lincln.

Cao, J., P.R. Henry, R.A. Holwerda, J.P. Toth, R.C. Littell, R.D. Miles and C.B. Ammerman, 2000. Chemical characteristics and relative bioavailability of supplemental organic zinc source for poultry and ruminants.J.Anim.Sci.78: 2039-2054.

Dinn, N.E, J.A. Shelford and L.J. Fisher, 1998. Use of the corn meal net carbohydrate and protein system and rumen-protected lysine and methionine to reduce nitrogen excretion from lactating dairy cows. J. Dairy Sci.,81:229-237.

Duncan, D.B. (1955). Multiple ranges and multiple F- test. Biometric, 11: 1-42.

El-Shazly, K.; E.I.A. Ahmed; M.A. Naga and B.E.A. Borhami (1976). A calorimetric technique using chromium-ethylen diamins tetracetate for measuring rumen volume. J. Agric. Sci. Camb., 87: 369.

France, J. and Siddons, J. (1993). Volatile fatty acids production. In: Forbes, J.M., France, J. (Eds)., Quantitation Aspects of Ruminal Digestion and Metabolism. (AB International Wallmyford, Oxon, UK. pp:107-121.

Froetschel, M.A., Martin, A.C., Amos, H.E. and Evans, J.J. (1990). Effect of zinc sulfate concentration and feeding frequency on ruminal protozoa numbers, fermentation pattern and amino acid passage in steers. J. Anim. Sci., 66: 1818-1823.

Gaafar, H.M.A. Bassiouni, M.I. Ali, M.F.E. Shitta, A.A. and Shamas, A.Sh.E. (2011). Effect of Zinc Methionine Supplementation on Productive Performance of Lactating Friesian Cows. J. Anim. Sci. Biotech. 2(2):94-101.

Garg, A.K. Mudgal, V. and Dass, R.S. (2008). Effect of organic zinc supplementation on growth, nutrient utilization and mineral profile in lambs. Anim. Feed Sci. Technol. 144: 82-96. 
Atia et al

Hideaki, T.; M. Makoto and I. Kenichi (2005). Effects of supplemental zinc methionine on fattening performance and meat quality of Japanese black steers. Research Bulletin of theAichi-ken Agricultural Research Center, 37: 159-165.

Huerta M, Kincaida RL, Cronratha JD, Busbooma J,Johnsonb AB, Swenson CK. 2002. Interaction of dietaryzinc and growth implants on weight gain, carcass traits and zinc in tissues of growing beef steers and heifers. Animal Feed Science and Technology 95:15-32.

Hungate, R.E. (1965). Quantitative aspects of the rumen fermentation. In: Physiology of Digestion in the Ruminant, Butterworth's Inc., Washington, DC.

Kleinschmit, D. H.; D. S. Schingoethe; K. F. Kalscheur and A. R. Hippen (2006). Evaluation of various sources of corn distillers dried grains plus solubles for lactating dairy cattle. J. Dairy Sci. 89:4784 - 4794.

Luo, X.G., P.R. Henry, C.B. Ammerman, J.B. Madison, 1996. Relative bioavailability of copper in a copper lysine complex or copper sulfate for ruminants as affected by feeding regimen. Anim. Feed Sci. and Technol. 57,281-289.

Mandal GP, Dass RS, Isore DP, Garg AK, Ram GC. 2007.Effect of zinc supplementation from two sources on growth, nutrient utilization and immune response in male crossbred cattle (Bos indicus_Bos Taurus) bulls.Animal Feed Science and Technology 138:1-12.

Miller. W. J., Amos, H. E., Gentry, R. P., Blakmon, D. M., Durance, R.M., Crowe, C. T., Fielding, A. S. And Neathery, M. W., 1989. Long-Term Feeding of High Zinc Sulfate to Lactating and Gestating Dairy Cows. J.Dairy sci. 72: 1499-1508.

Mousa, Kh. M.M. and S.M.EL-Sheikh, 2004. Effect of different levels of zinc supplementation on utilization of non-protein nitrogen for lactating buffaloes. J. Agric. Sci. Mansoura Univ., 29(6): 3063-3073.

N.R.C (1994). Nutrient requirements of sheep. Academy of Sciences. National Research Council, Washington, D.C.

Preston, T.R. (1995). Biological and for research workers. Rome: FAO, 1995. Chap. 9, p.191- Animal Feeding: A manual for research workers. Rome: FAO, 1995. Chap, p.191- 264.

Rink, L. and H. Kirchner, 2000. Zinc-altered immune function and cytokine production. J Nutr 30:14071411.

Roth, H. P., Schulein, A. and Kirchgessner, M. (1992). Influence of alimentary zinc deficiency on digestibility of nutrients and zinc utilization in force fed rats. Journal of Animal Physiology and Nutrition (Germany), 68: 136-145.

Saeid Sobhanirad, Dorthe Carlson and Reza Bahari Kashani, 2010. Effect of Zinc Methionine or Zinc Sulfate Supplementation on Milk Production and Composition of Milk in Lactating Dairy Cows. Biol Trace Elem Res., 136:48-54.

Salama AAK, Caja G, Albanell E, Such X, Caslas R, Plaixats. (2003). Effects of dietary supplements of zinc-methionine on milk production, udder health and zinc metabolism in dairy goats. J Dairy Res; 70: 917.

SAS, 2006. User's Guide, Release 9.3.1. SAS Institute Inc., SAS/STAT ${ }^{\mathrm{TM}}$, Statistical Analysis System Institute Inc., Cary, NC.

Shakweer, I.M.E., A.A.M. EL-Mekass and H.M. EL-Nahas, 2006. Effect of supplemental zinc methionine concentrations on digestibility, feed efficiency and some ruminal and blood parameters and performance of Friesian calves. J. Agric. Sci. Mansoura Univ.,31(8): 4935-4935.

Shakweer, I.M.E., A.A.M. EL-Mekass and H.M.EL-Nahas, 2005. Effect of different levels of supplemented organic zinc source on performance of Friesian dairy cows. J. Agric. Sci. Mansoura Univ. 30(6): 3025 3035 .

Spears, J.W.; P. Schlegelb; M.C. Seal and K.E.Lloyd (2004). Bioavailability of zinc from zinc sulfate and different organic zinc sources and their effects on ruminal volatile fatty acid proportions .Livestock Production Science, 90: 211-217. 
Van Soest, P. J., Robertson, J. B. And Lewis, B. A., 1991. Methods of dietary fibre, neutral detergent fibre, and non starch polysaccharide in relation to animal nutrition. J. Dairy Sci., 74: 3583-3597.

Van Soest, P.J. (1982). Nutritional ecology of the ruminant. Corvallis, Oregon, O \& B Books.

Walker, D.J. (1965). Energy metabolism and rumen microorganisms. In: Physiology of Digestion in the Ruminants. Butterowrth Inc., Washington, DC.

Warner, A.C.I. (1964). Production of volatile fatty acids in the rumen, methods of measurement. Nutr. Abst. and Rev., 34: 339.

\footnotetext{
تاثير مصدر الزنك (الغير عضوى مقابل العضوى) والمضاف للعلاثق على الهضم و تخمرات الكرش للاغنام

صفاء السيد عطية1 و عبد العزيز محمد الحايس1 وشريف عبد الونيس جبر1 و محمد حلمى ياقوت2 و ايمن عبد المحسن حسن و محمد سمير خليل 2

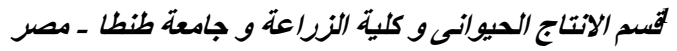

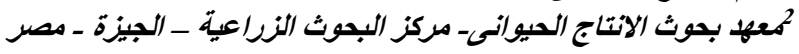

نفذت هذه الدر اسة بهدفالتحقق من تاثير اضافة كبريتات الزنكك و و الزنكك مثيونين على هضم المكونات الغذائية و القيمة الغذائية

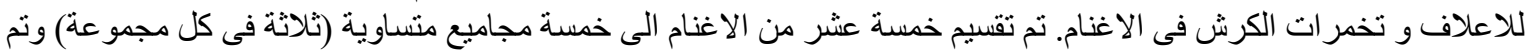

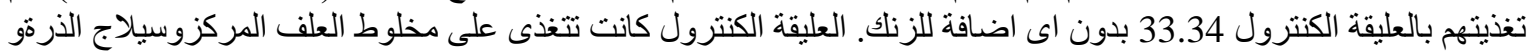

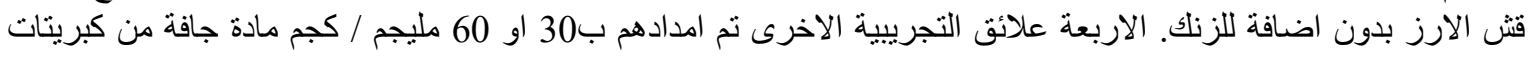

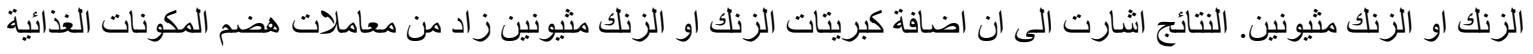

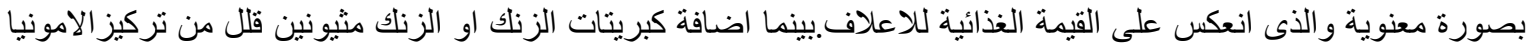
وزياده تركيزكلا من الاحماض الدهنية الطيارة وكميه البروتين الميكروبى المخلق بالكرش في الإنى الغنام.
} 